\title{
THE EFFECT OF TWO PLANTING METHODS ON THE SURVIVAL AND GROWTH OF WHITE SPRUCE (Picea glauca (MOENCH) VOSS) IN EASTERN ONTARIO
}

\author{
By K. A. ARMSON
}

K. A. Armson obtained his B.Sc.F. at the University of Toronto in 1951. After graduation he worked with the Division of Research, Ontario Department of Lands and Forests until 1952. In 1952 he was appointed Lecturer in Forestry at the Faculty of Forestry, University of Toronto. During a year's leave-of-absence he did graduate work at Oxford University and received the Diploma in Forestry in 1955.

\section{ABSTRACT}

White spruce trees were planted in the Larose County Forest, Ontario, on a sandy soil which has a permanent water table 6-24 inches below the surface. In one method of planting the trees were placed in the bottom of the furrow, and in a second method they were planted in the upturned furrow slice. Eight years after planting there was found to be no difference in the survival rates of trees planted by either method, but the height of those trees planted in the upturned furrow slice was significantly greater than that of trees planted in the bottom of the furrow. The difference in height appeared to be related to the fact that those trees planted in the furrow bottoms had their roots placed in a zone of the soil which is seasonally saturated with water.

The poor height growth of many white spruce plantations of the Larose County Forest in Ontario has been attributed to imperfect soil drainage. In 1948 a planting experiment ${ }^{1}$ was carried out to determine whether by planting a tree in a better-drained position, i.e. in an upturned furrow slice rather than the bottom of a furrow, height growth could be improved.

This forest is situated south of the Ottawa River approximately 25 miles southeast of Ottawa, and is in the physiographic region termed the Prescott and Russell Sand Plains by Chapman and Putnam (1951). These sands are deltaic in origin and are underlain by clay at varying depths of 10-30 feet. The topography is quite level, and the elevation is approximately 250 feet above sea level.

The experimental plantation was established on land withdrawn from agricultural use, and the soil is a fine sand in texture with a permanent water table at varying depths of 6-24 inches from the surface.

\section{METHODS}

In May 1948 the experimental area of approximately 6 acres was ploughed with single furrows 7 feet apart. The depth of furrow was approximately 7 to

Received for publication, January 22, 1958.

${ }^{1}$ Suggested by W. E. Steele, then District Forester, Rideau District, Ontario Department of Lands and Forests. 
8 inches. In alternate furrows white spruce $(2+2)$ were hand planted 7 feet apart. In the remaining furrows the trees were hand planted in the upturned furrow slices.

In July 1956 six randomly selected $1 / 20$ acre plots were laid out in the experimental area, and the heights of the trees measured to the nearest tenth of a foot. Since height growth extension for the 1956 growing season was not complete at the time of measurement, current (1956) height growth was not included. In addition, an estimate of the number of trees surviving in 1956 was made. The root systems of trees planted by each method were excavated and drawings made.

\section{Results AND Discussion}

The percentage survival of the trees in 1956 is given in Table 1. The number of trees planted in 1948 had to be estimated on the basis of a 7 foot planting interval, since a count of the trees actually planted was not kept.

TABLE I

Percentage Survival of Trees in 1956

\begin{tabular}{ccccc}
\hline & $\begin{array}{c}\text { Estimated No. } \\
\text { of trees } \\
\text { planted 1948 }\end{array}$ & & $\begin{array}{c}\text { No. of trees } \\
\text { surviving 1956 }\end{array}$ & $\begin{array}{c}\text { Percentage } \\
\text { Survival }\end{array}$ \\
\cline { 2 - 3 } $\begin{array}{c}\text { Planted in furrow } \\
\text { Planted in upturned } \\
\text { furrow slice }\end{array}$ & 126 & & 99 & 78.6 \\
\hline
\end{tabular}

The mean heights of the trees and the standard errors of the means are presented in Table 2. The difference between the mean heights of $0.68 \mathrm{ft}$. is significant at the $1 \%$ level of significance.

TABLE II

Mean Heights and Standard Errors of the Means

\begin{tabular}{lcc}
\hline Planting Method & No. of trees & Mean Heights 1956 \\
\cline { 2 - 3 } $\begin{array}{l}\text { Planted in furrow } \\
\begin{array}{c}\text { Planted in upturned } \\
\text { furrow slice }\end{array}\end{array}$ & 99 & $1.59 \pm 0.08 \mathrm{ft}$. \\
\hline
\end{tabular}

Although there is no significant difference between the survival rates of the trees planted by either method, those planted in the upturned furrow slice show a significantly greater mean height than those planted in the furrow. Langdon (1956) in a similar experiment with slash pine noted that three years after the planting the height growth of those trees planted in the furrow ridges was much greater than those trees planted in the furrow, and also the survival of the trees on the ridges was three times greater. 
In Figure 1 diagrams of the root systems associated with trees planted in each of the two planting positions are shown. In planting tree $\mathrm{A}$ in the furrow, the root system is placed in soil which is seasonally saturated. The planting was done in May, and it is at this time of year that the soil is so saturated. As a

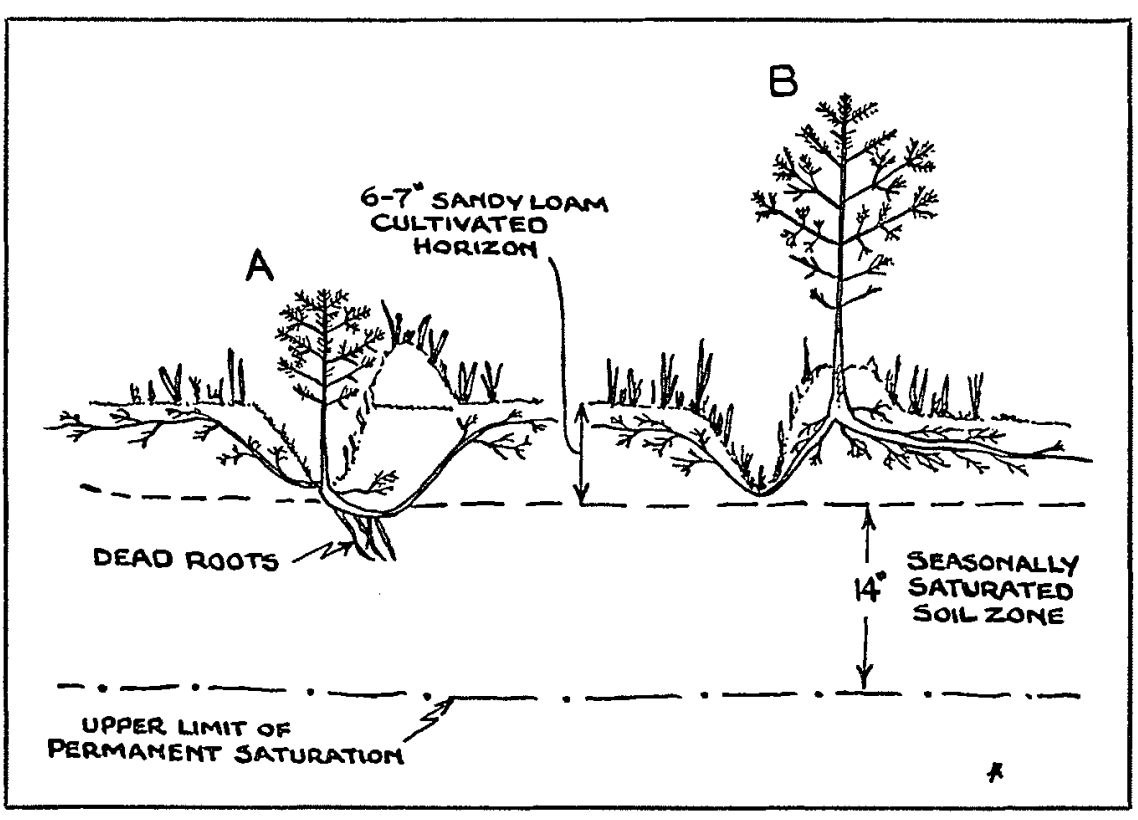

FIGURE 1

Diagram showing white spruce eight years after planting.

A-tree planted in bottom of furrow

B-tree planted in upturned furrow slice

consequence, much of the original root system is dead. The main present live root system consists of an adventitious root and an extension of one of the original roots. Both of these main roots have their associated fine roots within 1-3 inches of the surface.

In contrast, the root system of tree B, planted in the upturned furrow slice, was placed in soil above the upper level of seasonal saturation. The original root system of this tree had grown and extended; the majority of the fine roots are within 1-3 inches of the soil surface as for tree A. Thus in the first few years after planting tree $B$ has a more vigorous root system than tree $A$, and consequently might be expected to show greater height growth, at least in this initial period. The fact that the major portion of the root systems of both trees are to be found within 1-3 inches of the surface would suggest that this region provides more favorable conditions for root growth, particularly better aeration. In Great Britain the improved growth of trees planted on inverted turfs in 
the afforestation of peat soils has been attributed to the better local drainage in the turf (Fraser 1933, Anon 1953).

That the growth of this eight-year-old plantation is unsatisfactory is indicated by the mean height ( 2.3 feet) of the trees planted in the upturned furrow slice. Few of the trees in the plantations carry needles more than two years old, and the foliage on the majority of trees is very short and chlorotic. It is suggested that although height growth has been improved somewhat by a planting method which does not put the root systems in a saturated zone of the soil, there are other factors limiting the growth, and these are most probably deficiencies of one or more nutrient elements.

\section{ACKNOWLEDGEMENTS}

The author wishes to thank Mr. W. Torrance for his assistance in obtaining the field data. This study was made during the summer 1956 while the writer was engaged in plantation studies for the Division of Reforestation, Ontario Department of Lands and Forests.

\section{Literature Cited}

Anon. 1953. Forestry Practice. Bulletin 14, 6th ed.-Forestry Commission, HMSO. London. 90 pp. CHAPMAN, L. J. and PUTNAM, D. F. 1951. The physiography of southern Ontario. University of Toronto Press, Toronto. 284 pp.

FRASER, G. K. 1933. Studies of certain Scottish moorlands in relation to tree growth. Bulletin 15, Forestry Commission, HMSO. London. 112 pp.

LANGDON, O. G. 1956. Elevation and tree growth. Southern Lumberman. 193: $2417: 191-192$. 